\title{
EVALUASI USABILITY DAN PERBAIKAN ANTARMUKA PADA LAMAN UTAMA KOMINFO.GO.ID
}

\author{
Santika Sari ${ }^{1}$, Amelia Rizky Ramadhanty ${ }^{2 *}$ \\ Program Studi Teknik Industri, Universitas Pembangunan Nasional Veteran Jakarta ${ }^{1,2^{*}}$ \\ santika.sari@upnvj.ac.id
}

Submitted March 30, 2021; Revised August 5, 2021; Accepted August 20, 2021

\begin{abstract}
Abstrak
Kementerian Komunikasi dan Informatika Republik Indonesia, sebagai garda terdepan penyampaian informasi di Republik Indonesia, laman Web utama memiliki peran sangat penting. Namun, ternyata masih banyak masyarakat yang mengeluhkan kesulitan dalam mengoperasikan fitur fitur di Laman Web Kementerian Komunikasi dan Informatika Republik Indonesia (kominfo.go.id), dan terdapat beberapa ketidaksesuaian fitur dengan faktor psikologi dan ergonomic. Masalah yang disebutkan diatas adalah masalah usability yang dihadapi oleh pengguna laman kominfo.go.id. Beberapa parameter yang dapat dijadikan patokan dalam mengukur kriteria-kriteria web usability adalah antara lain mencakup Learnability, Efficiency, Memorability, Errors, dan Satisfaction. Metode penyelesaian yang akan digunakan adalah dengan pengujian usability, pengujian usability akan dilakukan dengan cara mengobservasi pengguna, kemudian diambil datanya lalu baru kemudian dianalisa, hasil analisa akan digunakan sebagai rujukan untuk saran perbaikan. Saran perbaikan dilakukan dengan cara mendesain ulang antarmuka laman web kominfo.go.id da beberapa metode dalam perancangan antarmuka laman web, salah satunya ialah dengan menggunakan metode Human Centered Design. Tingkat Usability dari laman web kominfo.go.id cukup jauh dari batas toleransi, dimana seharusnya setidaknya $75 \%$ tingkat efisiensi, kominfo.go.id hanya memperoleh $18 \%$ tingkat efisiensi. Maka perlu diadakannya perbaikan user interface
\end{abstract}

Kata Kunci : Laman Web, Usability, Human-Centered Design.

\begin{abstract}
As the vanguard of information delivery, the Ministry of Communication and Information Technology of the Republic of Indonesia has a main Web Page with a prominent role. However, it turns out that there are still many people who complain about the difficulty in operating some features on the Ministry of Communication and Information Technology's Web Page (kominfo.go.id) and about the mismatches between the features and psychological and ergonomic factors. These are the usability problems found on the kominfo.go.id page. Some parameters that can be used as benchmarks in measuring web usability criteria are comprised of Learnability, Efficiency, Memorability, Errors, and Satisfaction. The settlement method that will be used is the usability testing to be carried out by observing the users, the data of which are taken and then analyzed to produce the results to be used as a reference for improvement suggestions. Improvement suggestions are realized by redesigning the interface of the kominfo.go.id web page using several methods in designing the web page interface, one of which is a Human-Centered Design method. The usability level of the kominfo.go.id web page is quite far from the tolerance limit. It should be at least $75 \%$ efficiency level, but kominfo.go.id only gets $18 \%$ efficiency level. Therefore, it is necessary to hold the improvement of the user interface
\end{abstract}

Keywords : Webpage, Usability, Human-Centered Design.

\section{PENDAHULUAN}

Laman web pada lembaga negara ditujukan untuk mempermudah dalam penyampaian informasi berupa profil lembaga, kabar terbaru tentang lembaga, informasi untuk publik, pengumuman, serta regulasi terbaru. Terlebih lagi untuk Kementerian Komunikasi dan Informatika Republik Indonesia, sebagai garda terdepan penyampaian informasi di Republik 
Indonesia, Laman Web utama memiliki peran sangat penting. Namun, ternyata masih banyak masyarakat yang mengeluhkan kesulitan dalam mengoperasikan fitur fitur di Laman Web Kementerian Komunikasi dan Informatika Republik Indonesia (kominfo.go.id), dan terdapat beberapa ketidaksesuaian fitur dengan faktor psikologi dan ergonomi seperti warna dan font, dan sulitnya untuk menemukan akses ke sublaman yang ingin dituju.

Melalui umpan balik yang disampaikan masyarakat via laman lapor.go.id dan laman pengaduan di laman kominfo.go.id, dapat disimpulkan bahwa laman kominfo.go.id masih memiliki beberapa masalah usability untuk para penggunanya. Untuk itu, maka diperlukan penggalian masalah terkait usability, untuk mengetahui sejauh mana masalahnya, apa yang menjadi inti masalah, dan untuk mengetahui sejauh mana tingkat usability. Usability adalah tingkat kemudahan pengguna ketika menggunakan aplikasi atau sebuah sistem [1]. Usability yang baik yaitu pengguna dapat menggunakan aplikasi secara cepat (effective), mendapatkan kepuasan (satisfaction), serta cara penggunaan aplikasi yang sederhana (efficiency) sebagai tingkat apakah suatu produk mudah untuk digunakan. Berdasarkan ISO usability dapat diartikan sebagai efektif, efesiensi, dan kepuasan yang ditentukan oleh pengguna dalam mencapai tujuan yang telah ditentukan sebelumnya [2]. Tingkat usabilitas suatu website dapat berbeda-beda dan tergantung bagaimana pengguna dapat menyelesaikan serangkaian task. Beberapa parameter yang dapat dijadikan patokan dalam mengukur kriteria-kriteria web usability adalah antara lain mencakup Learnability, Efficiency, Memorability, Errors, dan Satisfaction [3]. Metode penyelesaian yang akan digunakan adalah dengan pengujian usability, pengujian usability akan dilakukan dengan cara mengobservasi pengguna, kemudian diambil datanya lalu baru kemudian dianalisa, hasil analisa akan digunakan sebagai rujukan untuk saran perbaikan. Kuisioner yang dapat digunakan untuk mengukur usability adalah USE, terdapat beberapa aspek pengukuran usability menurut Ido yaitu efesiensi, efektivitas dan kepuasan [4]. Beberapa penelitian yang sudah dilakukan menunjukan bahwa kebanyakan evaluasi produk mengacu pada tiga dimensi. Hasil beberapa pengamatan juga menunjukan adanya korelasi dan saling mempengaruhi antara parameter ease of use dan usefulness.

Penulis memilih metode Human-Centered Design memiliki tujuan yaitu untuk mengurangi ketidaknyamanan. mengurangi stress, memperbaiki usability, dan juga untuk memperbaiki user experience laman web [5].

Dalam kajian Human Computer Interaction (HCI), ada banyak hal yang mempengaruhi keergonomisan suatu perangkat lunak, dan hal tersebut dapat sangat berpengaruh terhadap kenyamanan pengguna dalam melakukan kegiatan (task) dan interaksi selama berada di lingkungan perangkat lunak tersebut [6]. Menurut [7] HCI merupakan disiplin ilmu yang terkait dengan desain, evaluasi dan implementasi dari sistem komputer interaktif untuk manusia dengan mempelajari kejadian utama yang ada disekelilingnya. Permasalahan usability merupakan salah satu masalah HCI pada perangkat lunak, dan pada kasus ini terjadi di laman web. Diperlukan adanya perbaikan HCI yang diawali dengan evaluasi usability yang dilanjutkan dengan perbaikan desain antarmuka untuk meningkatkan User Experience (UX), sehingga kualitas HCI pada laman web dapat menjadi lebih baik dan lebih ergonomis.

Dari masalah diatas penulis mengangkat tema "Analisis perbaikan Human Computer Interaction melalui evaluasi Usability dan perbaikan antarmuka secara 
Human Centered Design pada laman utama kominfo.go.id".

\section{METODE PENELITIAN}

\section{Metode Pengumpulan Data}

Metode pengumpulan data merupakan Langkah yang dilakukan untuk mengumpulkan data untuk kepentingan penelitian. Dalam penelitian ini, langkahlangkah yang dilakukan adalah sebagai berikut :

1. Wawancara

Yaitu teknik pengumpulan data dengan cara melakukan tanya jawab secara langsung dengan pihak yang mengetahui mengenai objek yang diteliti yaitu dengan pihak Front-End developer Kominfo RI. Wawancara dilakukan untuk melakukan pengumpulan data yang diperlukan terkait website kominfo.go.id. Data-data yang diperlukan seperti jumlah pengguna yang mengunjungi website kominfo.go.id perhari. Selain itu, untuk mendapatkan data jumlah laporan yang masuk ke dalam website kominfo.go.id serta jumlah pengguna kominfo.go.id.

2. Pengujian

Pengujian dilakukan dengan cara memberi skenario kepada responden yang berjumlah 15 (lima belas) orang, responden terdiri atas pegawai yang bekerja sebagai back-end engineer, pegawai yang bekerja sebagai front-end engineer, orang awam tentang teknologi informasi, orang tidak awam tentang teknologi informasi yang bukan pegawai, dan pegawai magang.

3. Penelitian Kepustakaan

Yaitu literature yang diperlukan untuk mengolah data yang diperoleh dalam penelitian untuk diolah lebih lanjut.

\section{Metode Pengolahan Data}

Langkah langkah yang digunakan dalam pengolahan data dalam menganalisa usability pada website kominfo.go.id.
1. Melakukan definisi responden dan pembuatan skenario tugas. Dalam metode Nielsen's Attributes of Usability (NAU) terdapat 5 (lima) poin pengujian yaitu Learnability, Efficiency, Memorability, Error, dan Satisfaction [8]. Skenario tersebut harus sesuai dengan poin-poin pengujian diatas. Terdapat 6 (enam) task yang akan dilakukan oleh responden. Task tersebut adalah sebagai berikut :

UT 0 : Membuka Halaman Web Kominfo.go.id.

UT 1 : Temukan fitur untuk melihat Laporan isu Hoax.

UT 2 : Telusuri konten web dengan keyword "Presiden".

UT 3 : Menuju ke halaman utama web UT 4 : Temukan fitur untuk menemukan berita terbaru.

UT 5 : Temukan fitur dimana kita bisa melakukan request informasi dan dokumen.

UT 6 : Terdapat kesalahan pada fitur berita berjalan/running text, temukan kesalahannya.

2.Melakukan Pengolahan data hasil pengisian kuesioner. Karena peneliti membuat kuesioner dengan menggunakan metode NAU, oleh karena itu pertanyaan yang diajukan pada kuesioner adalah merupakan subpoin-subpoin dari NAU itu sendiri.

\section{HASIL DAN PEMBAHASAN}

Pada proses pengumpulan data peneliti melakukan proses wawancara kepada 15 orang responden via aplikasi conference call google meet, wawancara berlangsung dengan cara responden berbagi layar, peneliti membacakan skenario dan task, selanjutnya responden melakukannya. Peneliti selanjutnya melakukan pengitungan waktu responden tiap tiap task menggunakn stopwatch.

Hasil pengujian usability pada tabel 1 tertera bagaimana responden 
menyelesaikan taks-nya apakah bisa dilaksanakan dengan sempurna atau tidak.

\begin{tabular}{|c|c|c|c|c|c|c|c|c|c|c|c|c|c|c|c|}
\hline \multirow{2}{*}{ TASK } & \multicolumn{15}{|c|}{ RESPONDEN } \\
\hline & 1 & 2 & 3 & 4 & 5 & 6 & 7 & 8 & 9 & 10 & 11 & 12 & 13 & 14 & 15 \\
\hline UT 1 & $\mathrm{v}$ & $\mathrm{v}$ & $\mathrm{v}$ & $\mathrm{x}$ & $\mathrm{x}$ & $\mathrm{v}$ & $\mathrm{v}$ & $\mathrm{v}$ & $\mathrm{v}$ & $\mathrm{x}$ & $\mathrm{x}$ & $\mathrm{v}$ & $\mathrm{v}$ & $\mathrm{v}$ & $\mathrm{v}$ \\
\hline UT 2 & $\mathrm{v}$ & $\mathrm{v}$ & $\mathrm{v}$ & $\mathrm{v}$ & $\mathrm{v}$ & $\mathrm{v}$ & $\mathrm{v}$ & $\mathrm{v}$ & $\mathrm{v}$ & $\mathrm{v}$ & $\mathrm{v}$ & $\mathrm{v}$ & $\mathrm{v}$ & $\mathrm{v}$ & $\mathrm{v}$ \\
\hline UT 3 & $\mathrm{~V}$ & $\mathrm{v}$ & $\mathrm{v}$ & $\mathrm{v}$ & V & $\mathrm{v}$ & $\mathrm{v}$ & $\mathrm{v}$ & $\mathrm{V}$ & $\mathrm{v}$ & $\mathrm{V}$ & $\mathrm{V}$ & $\mathrm{v}$ & $\mathrm{v}$ & $\mathrm{v}$ \\
\hline UT 4 & $\mathrm{v}$ & $\mathrm{v}$ & $\mathrm{v}$ & $\mathrm{v}$ & $\mathrm{v}$ & $\mathrm{v}$ & $\mathrm{v}$ & $\mathrm{v}$ & $\mathrm{V}$ & $\mathrm{v}$ & $\mathrm{v}$ & $\mathrm{v}$ & $\mathrm{v}$ & $\mathrm{V}$ & $\mathrm{v}$ \\
\hline UT 5 & $\mathrm{v}$ & $\mathrm{v}$ & $\mathrm{V}$ & $\mathrm{v}$ & $\mathrm{v}$ & $\mathrm{v}$ & v & $\mathrm{x}$ & V & $\mathrm{V}$ & $\mathrm{V}$ & $\mathrm{V}$ & $\mathrm{V}$ & $\mathrm{V}$ & $x$ \\
\hline UT 6 & $\mathrm{x}$ & $\mathrm{x}$ & $\mathrm{x}$ & $\mathrm{x}$ & $\mathrm{V}$ & $\mathrm{v}$ & $\mathrm{x}$ & $\mathrm{x}$ & $\mathrm{x}$ & $\mathrm{x}$ & $\mathrm{x}$ & $\mathrm{x}$ & $\mathrm{v}$ & $\mathrm{x}$ & $\mathrm{x}$ \\
\hline
\end{tabular}

\section{Gambar 1. Hasil Pengujian}

Keterangan :

$\mathrm{v}=$ dapat menyelesaikan task dengan baik

$\mathrm{x}=$ tidak dapat menyelesaikan task dengan baik

Penulis memilih 15 responden untuk pengujian usability ini, karena menurut kurva yang dijelaskan oleh [3] menunjukkan bahwa dalam melakukan pengujian perlu menguji dengan setidaknya 15 pengguna untuk menemukan semua masalah kegunaan dalam desain. Berikut hasil rekapitulasi karakteristik responden berdasarkan data kuesioner yang diberikan oleh penulis. Usability testing yang dilakukan memiliki rata-rata pengerjaan waktu 37.6 detik setiap responden, dan memiliki rata - rata waktu 9.1 detik setiap task

\begin{tabular}{|c|c|c|c|c|}
\hline \multicolumn{3}{|c|}{ Pertanyaan } & \multirow{2}{*}{$\begin{array}{c}\begin{array}{c}\text { Modus } \\
\text { Jawaban }\end{array} \\
4\end{array}$} & \multirow{2}{*}{$\begin{array}{r}\text { Keterangan } \\
\text { Setuju }\end{array}$} \\
\hline \multirow{3}{*}{ Learnability } & 1 & $\begin{array}{c}\text { Saya dapat mempelajari web } \\
\text { dengan mudah }\end{array}$ & & \\
\hline & 2 & $\begin{array}{l}\text { saya memperoleh informasi } \\
\text { yang spesifik dengan mudah }\end{array}$ & 5 & $\begin{array}{l}\text { Sangat } \\
\text { Setuju }\end{array}$ \\
\hline & 3 & $\begin{array}{l}\text { Saya dapat memahami alur } \\
\text { navigasi dengan mudah }\end{array}$ & 3 & $\begin{array}{l}\text { Cukup } \\
\text { Setuju }\end{array}$ \\
\hline \multirow{3}{*}{ Efficiency } & 4 & $\begin{array}{l}\text { Saya Dapat mengakses fitur } \\
\text { dengan cepat }\end{array}$ & 4 & Setuju \\
\hline & 5 & $\begin{array}{c}\text { Saya dapat memperoleh } \\
\text { informasi yang dicari dengan } \\
\text { cepat }\end{array}$ & 3 & $\begin{array}{l}\text { Cukup } \\
\text { Setuju }\end{array}$ \\
\hline & 6 & $\begin{array}{c}\text { Saya dapat melakukan tugas } \\
\text { pengujian dengan cepat dan } \\
\text { tepat }\end{array}$ & 5 & $\begin{array}{l}\text { Sangat } \\
\text { Setuju }\end{array}$ \\
\hline \multirow{2}{*}{ Memorability } & 7 & $\begin{array}{c}\text { Saya mengingat cara } \\
\text { penggunaan website dengan } \\
\text { mudah }\end{array}$ & 5 & $\begin{array}{l}\text { Sangat } \\
\text { Setuju }\end{array}$ \\
\hline & 8 & $\begin{array}{l}\text { Saya dapat mengingat cara } \\
\text { penggunaan website kembali } \\
\text { setelah jarak waktu tertentu }\end{array}$ & 3 & $\begin{array}{l}\text { Cukup } \\
\text { Setuju }\end{array}$ \\
\hline \multirow[b]{2}{*}{ Error } & 9 & $\begin{array}{c}\text { Saya tidak berhasil } \\
\text { menemukan menu yang dicari }\end{array}$ & 2 & $\begin{array}{l}\text { Kurang } \\
\text { Setuju }\end{array}$ \\
\hline & 10 & $\begin{array}{l}\text { Saya menemukan error disaat } \\
\text { menggunakan website }\end{array}$ & 1 & $\begin{array}{l}\text { Sangat } \\
\text { Tidak } \\
\text { Setuju }\end{array}$ \\
\hline \multirow{3}{*}{ Satisfaction } & 11 & $\begin{array}{l}\text { Saya merasa senang dengan } \\
\text { keseluruhan desain website }\end{array}$ & 3 & $\begin{array}{l}\text { Cukup } \\
\text { Setuju }\end{array}$ \\
\hline & 12 & $\begin{array}{l}\text { Saya merasa nyaman dalam } \\
\text { menggunakan website }\end{array}$ & 3 & $\begin{array}{l}\text { Cukup } \\
\text { Setuju }\end{array}$ \\
\hline & 13 & $\begin{array}{l}\text { Desain (pemilihan warna dan } \\
\text { font) di dalam website sangat } \\
\text { baik }\end{array}$ & 4 & Setuju \\
\hline
\end{tabular}

Gambar 2. Karakteristik Responden
Waktu tercepat dilakukan oleh responden 4 dengan catatan wakt 18.91 detik dan waktu terlama dicatat oleh responden 13 dengan catatan waktu 61.42 detik. Berikut merupakan tabel rekapitulasi jumlah waktu.

Tabel 2. Rekapitulasi Jumlah Waktu

\begin{tabular}{ccl}
\hline Responden & Jumlah waktu & Ket. \\
\hline 1 & 35,61 & $\mathrm{x}$ \\
2 & 38,27 & $\mathrm{x}$ \\
3 & 35,25 & $\mathrm{x}$ \\
4 & 18,91 & $\mathrm{x}$ \\
5 & 44,23 & $\mathrm{v}$ \\
6 & 54,49 & $\mathrm{v}$ \\
7 & 36,06 & $\mathrm{x}$ \\
8 & 27,99 & $\mathrm{x}$ \\
9 & 35,88 & $\mathrm{x}$ \\
10 & 29,47 & $\mathrm{x}$ \\
11 & 36,58 & $\mathrm{x}$ \\
12 & 35,2 & $\mathrm{x}$ \\
13 & 61,42 & $\mathrm{v}$ \\
14 & 42,35 & $\mathrm{x}$ \\
15 & 32,34 & $\mathrm{x}$ \\
\hline Rata-rata & $\mathbf{3 7 , 6 0 3 3 3}$ & \\
\hline
\end{tabular}

Sesuai dengan studi yang dilakukan oleh [9] yang menyatakan bahwa Tingkat Penyelesaian Tugas rata-rata adalah $78 \%$ [10]. Maka akan dihitung tingkat Keseluruhan Efisiensi Relatif (KEF) pada usability testing ini, keberhasilan dan jumlah waktu didapatkan dari tabel 5 .

$$
\begin{aligned}
\operatorname{KEF}(1) & =\frac{\sum \text { Keberhasilan } \times \text { waktu }}{\text { Jumlah Waktu }} \\
= & \frac{(1 \times 44,23)+(1 \times 61,42)}{564,05} \times 100 \% \\
& =18,73 \%
\end{aligned}
$$

Dari hasil perhitungan KEF diatas maka disimpulkan bahwa website kominfo.go.id tidak efisien karena nilai minimum KEF untuk efisiensi adalah $75 \%$ [11] sedangkan website kominfo.go.id hanya mendapatkan KEF sebesar 18,73\%, maka 
diperlukan adanya perbaikan berdasarkan Analisa kesalahan-kesalahan yang dilakukan oleh responden dan beberapa keluhan yang disampaikan oleh responden.

Berdasarkan penjelasan pada parameter tingkat penyelesaian skenario tugas dan kesalahan, menunjukan masalah-masalah yang dihadapi oleh pengguna ketika memakai situs web Kominfo.go.id, maka perlu dilakukan perbaikan-perbaikan. Meskipun persentase-persentase menunjukan bahwa tingkat keefektifan dan keefisiensian web Kominfo.go.id sudah baik, namun masih banyak masukan atau rekomendasi yang diberikan oleh responden untuk perbaikan web Kominfo.go.id gar lebih baik atau memenuhi kepuasan para pengguna nantinya.

Tampilan Laman web sebelum dan sesudah perbaikan :

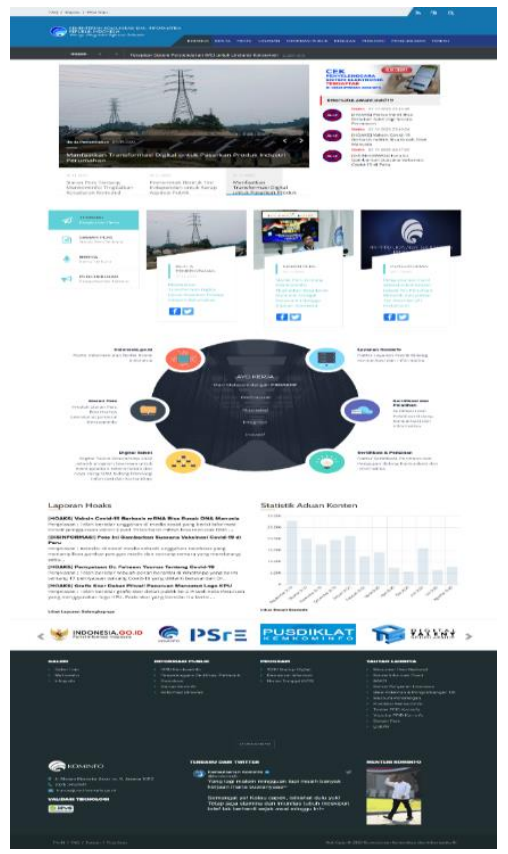

Gambar 3. Tampilan Sebelum
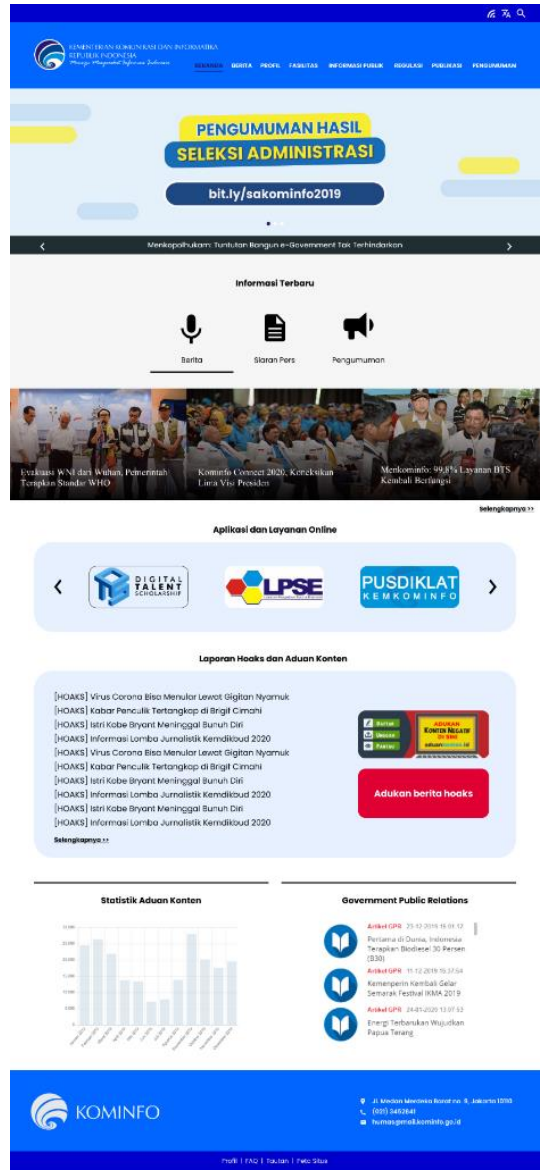

Gambar 4. Tampilan Sesudah

\section{SIMPULAN}

Dari analisis dan pembahasan yang telah dilakukan, maka dapat diambil simpulan bahwa tingkat Usability dari laman web kominfo.go.id cukup jauh dari batas toleransi, dimana seharusnya setidaknya $75 \%$ tingkat efisiensi, kominfo.go.id hanya memperoleh $18 \%$ tingkat efisiensi. Maka perlu diadakannya perbaikan user interface. Perbaikan dilakukan berupa perubahan jenis font, dan perubahan pemilihan warna. Selain itu, dilakukan juga perubahan penempatan beberapa fitur.sxd Beberapa responden mengeluhkan perihal navigasi, dan pemilihan warna dan font pada laman web kominfogo.id, oleh sebab itu desain yang dilakukan ditekankan pada hal-hal yang disebutkan diatas. 


\section{DAFTAR PUSTAKA}

[1] Albert, Bill. Me asuring The User Experience. MA:Burlington. 2008.

[2] Rahadi, Dedi Rianto. Pengukuran Usability Sistem Menggunakan Use Questionnaire Pada Aplikasi Android. Jurnal Sistem Informasi (JSI), VOL. 6, NO. 1, 2014.

[3] Nielsen, Jacob. Usability Engineering. San Francisco:Academic Press INC. 1994.

[4] Wardani, N.L.S., Darmawiguna, I.G. \& Sugihartini, N. Usability Testing Sesuai dengan ISO 9241-11 pada Sistem Informasi Program Pengalaman Lapangan Universitas Pendidikan Ganesha Ditinjau dari Pengguna Mahasiswa. Kumpulan Artikel Mahasiswa Pendidikan Teknik Informatika (KARMAPATI) Vol. 8.2019

[5] Murein, Miksa Mardhia \& Bariyah, Choirul. "Analisis Beban Kerja Mental Terhadap Aplikasi Dengan Antarmuka Cerdas”. Jurnal Teknologi Informasi dan Ilmu Komputer (JTIIK). Vol. 7, No. 1, 131-138. 2020.

[6] Pujadi, Tri. Faktor Manusia dan Ergonomis Penggunaan Komputer Untuk Meningkatkan Kesehatan danKeselamatan Kerja (K3). CommIT Vol.2. 2008.
[7] Dix, A., Finlay J., Abowd, G. D. \& Beale R. Human-Computer Interaction Third Edition. England:Pearson. 2004.

[8] Handiwidjodjo, W. \& Ernawati, L. Pengukuran Tingkat Ketergunaan (Usability) Sistem Informasi Keuangan Studi Kasus: Duta Wacana Internal Transaction (Duwit). JUISI Vol. 02. 2016.

[9] Dewi,Iunike Kartika, Mursityo,Yusi Tyroni, \& Putri, Rekyan Regasari. "Analisis Usability Aplikasi Mobile Pemesanan Layanan Taksi Perdana Menggunakan Metode Webuse Dan Heuristic Evaluation". Jurnal Pengembangan Teknologi Informasi dan Ilmu Komputer. Vol. 2, No. 8, 2909-2918. 2018.

[10] Lewis, James \& Sauro, Jeff. Revisiting The Factor Structure of The System Usability Scale. 2017.

[11] Farouqi,M.Ismail, Aknuranda,Ismiarta, \& Herlambang,Admaja dwi. "Evaluasi Usability Pada Aplikasi Go-Jek Dengan Menggunakan Metode Pengujian Usability". Jurnal Pengembangan Teknologi Informasi dan Ilmu Komputer. Vol. 2, No. 9, 3110-3117. 2018. 